\title{
InVESTIGATING Terminologies IN TEACHING Literature: A CORPUS STUDY
}

\author{
Agista Nidya Wardani ${ }^{1)}$, Adityo ${ }^{2)}$ \\ 1) University of Muhammadiyah Malang, Indonesia \\ E-mail: agista@umm.ac.id \\ 2) University of Muhammadiyah Malang, Indonesia \\ E-mail: adityo@umm.ac.id
}

\begin{abstract}
Regarding the literature subjects provided by the English Language Education Department, University of Muhammadiyah Malang, some students conduct researches on literature in their thesis. They find difficulties in doing the research as lacking of experience in discussing the thing and lacking vocabulary in describing terminologies. This research was designed to help the students whose major is English Education to maintain their study, especially on teaching English literature by finding out the terminologies in teaching literature books in terms of their frequency, example of their use, and meaning (in context). The objects of this research are Teaching and Learning English Literature by Ellie Chambers and Marshall Gregory, and Teaching Holocaust Literature and Film by Robert Eaglestone and Barry Langfor (Ed.) talking about teaching literature. The research method is document analysis. In number, there is no significant difference between them. No literary terminology that is more than 250 words. Beside, since they talk the same scope, the meanings of the terminologies are the same. Further, both present different use of terminologies. In some sentences, the terminologies are used to explain something closer to literature, yet in some other sentences, the terminologies are used to describe or explain the things related to teaching literature.
\end{abstract}

Keywords: Corpus; Literature; Teaching; Terminology

\section{INTRODUCTION}

Many sources, either books or journals, on literature are available. They are widely used, especially for those who study about literature and use them specifically in doing research on literature. In more detail, some of the sources talk about teaching literature. This more specific scope is needed for those who study English Education and want to have study on teaching (English) literature.

To ease the students' understanding on literature and to ease their research on the same field, a book covering lists of terminologies of literature as well as its meaning (in context) and example of its use is necessary. Particularly in English Language Education Department, Faculty of Teacher Training and Education, University of Muhammadiyah Malang, the ratio of literary subjects is relatively small. Starting from 2017, the subjects related to literature are Introduction to Literature ( 2 credits) and Literature in English Language Teaching ( 3 credits). Before 2017, the literature-related subjects were more various and plentiful that were Introduction to Literature ( 2 credits), Poetry (2 credits), Prose ( 2 credits), and Drama ( 2 credits). Among the literature subjects provided by the department, the more plentiful or the less one, there are students who conduct researches on literature in their thesis. Most of them find difficulties in doing the research as lacking of experience in discussing the thing as well as lacking vocabulary in describing terminologies they want to use. This research was designed to help the students whose major is English Education to maintain their study in English Education and their research on teaching English literature.

In doing so, this research would gather some books discussing about teaching English literature and find out the literary terminologies used in in it appearing in those books. Literature

According to Wellek and Warren (1963), literature is the manifestation of author's imagination. Meanwhile, Klarer (2004) states that literature is any written form that has aesthetic value. In addition to these definitions of literature, that makes literature wider is the consideration that all texts are actually literature. All that could be read are literature.

Literary Theory and Criticism

Literary theory and literary criticism are two things frequently joint. Literary theory is a theory used to examine a literary text, while literary criticism is when the literary theory is applied to examine the literary text. Basically, there are many kinds of literary theory, yet they could be divided into four categories or mostly called as approaches. They are 
mimetic approach, pragmatic approach, expressive approach, and objective approach (Abrams, 1953).

First, mimetic approach is concerns on the relationship between literature and the structure outside. In mimetic approach, it is believed that literary work has something to do with things outside it. The world outside it means the social background, history, or anything else happening when the literary work is made.

Second, pragmatic approach. The focus of pragmatic approach is the relationship of literary work and its reader. Pragmatic approach believes that literary work influences the reader.

Third, expressive approach. Expressive approach concerns on the link between the literary work and its author. It is called 'expressive' as it is believed that the literary work is its author's expression to manifest their thought.

Last, objective approach. Objective approach focuses on the literary work itself. It means that literary work is what is presented inside the work only. Nothing outside the literary work involved in determining the meaning of the literary work.

\section{Literary Work and the World Outside It}

As argued by Abrams (1953), one of literary approach is mimetic approach. One of literary theories that suit this approach is sociology of literature. In The Sociology of Literature, it is stated "Sociology is essentially the scientific, objective study of man in society, the study of social institutions and of social processes; it seeks to answer the question of how society is possible, how it works, why it persists" (Laurenson \& Swingewood, 1972:11). It is seen that literary work is the manifestation of the world outside it, especially the social condition when the literary work was made.

\section{Literary Work and Its Reader}

One of literary theories covered in pragmatic approach is reader-response theory. There is a close relationship between a literary work and its reader (Jauss, 1982). To this theory, a literary work is given a meaning through a process of creativity done by the reader. Thus, reader is one of fundamental aspects in literature. Literary work is meant to be the mixture of its existence and reader's interpretation.

Additionally, in this theory, reader is considered the one who 'awaken' the existence of a literary work by building awareness to the literary work. It happens, of course, not by being free from subjectivity. Even, the meaning of a literary work changes from past to present. Thus, the past meaning of a literary work depends on the present meaning (Gadamer in Hasanah, 2017). It is because what the reader thinks in the present is associated with what happens today which is truly different from the past.

Literary Work and Its Author

A literary work has a tight bond with its author. As Abrams (1953) says it about expressive approach. To Abrams, a literary work is the author's imagination.

Nevertheless, there is another argument that literary work has no purpose (Compagno, 2012). In other words, there is no correlation between a literary work and its author.
Aside from these two different point of views, the author still actually posits an important role, since a researcher will go back to the author when they want a meaning of a literary work to its origin (Compagno, 2012).

Some of literary theories covered in this approach are psychoanalysis, feminism, Marxism, and many more which can be focused on the thought of the author.

\section{Literary Work Itself}

The objective approach as stated by Abrams (1953) deals with what is inside the literary work itself. Some of literary theories covered in this approach are formalism, psychoanalysis, feminism, Marxism, and many more. For the last three, they can be applied in this approach when they are made to focus to analyze the characters or events inside the literary work.

In the case of formalism, it analyzes the structure of a text, like characters, characterization and plot, and other intrinsic elements. It is the same as older theory that explain a literary work in a thematic level (Klarer, 1999).

\section{Teaching Literature}

In teaching literature, common strategies of teaching are used. They are (1) pre-instruction, (2) instruction, (3) assessment, and (4) evaluation (Permanaludin, 2017). Again, in Permanaludin (2017), it is stated that teachers should master the teaching strategies and methodologies in order to deliver literary genres, like poetry, prose, and drama. Regarding to this, Leslie Stratta (in Endraswara, 2005) states that there are three steps of teaching literature that are (1) tuning, (2) interpreting, and (3) recreating.

\section{Corpus}

Corpus is a set of words, which is systematically arranged as it follows a certain extralinguistic system. Corpus for dictionaries was made firstly in the mid-1970s (Budiwiyanto, 2014).

In a corpus research, the researcher may consider among important points, some of them are meanings, frequencies, and word sense and use (Munday in Zemke, 2017).

According to Hartmann (2005), it is new that dictionary is more specific. Dictionaries or glossaries are now highly needed due to its specific information (Karpova, 2019).

Previous Study

The research done by Wardani and Adityo (2021) focused on finding out the frequency, example of the use, and meaning (in context) of literary terminologies. The research examined one Literature book and one Literature in English Language Teaching book. From the research, it was found that the frequency of the same terminologies found in Literature in English Language Teaching is far less than what it was found in Literature book. As examples, "poetry" in Literature and Language Teaching book are 150, while in Literary Movements for Students book are 936. Another example is the word "modernism". In the first book, it is mentioned only one time, while in the second one it is mentioned 467 times.

This research is in its second year. Previously, the researcher has composed bilingual mini corpus on literary terminologies found in books of Literature in English Language Teaching and Literary Theories. Differently, this 
year, the researcher would deepen the previous research by investigating literary terminologies used in books of teaching literature.

\section{METHODS}

This research uses document analysis. The objects of the study in this research were two books discussing teaching literature, namely Teaching and Learning English Literature written by Ellie Chambers and Marshall Gregory published in 2006 by Sage Publications, and Teaching Holocaust Literature and Film edited by Robert Eaglestone and Barry Langfor published in 2008 by Palgrave Macmillan. The books were published in the last ten years. The reasons lie behind choosing these books are both books provide the teaching of literature which contain terminologies related to literature and teaching literature. Besides, the publishing time of the books are considered the latest for sources used in this research.

The data collection techniques are 1) skimming the books, and 2) listing terminologies related to literature and teaching literature. Further, the data analysis techniques are 1) confirming the data to the theories used, and 2) drawing conclusion.

\section{RESULTS AND DISCUSSION}

Here are terminologies found in books of teaching literature as well as their frequency, meaning, and example of usage.

TABLE I

TERMINOLOGIES IN TEACHING LITERATURE ON TEACHING AND LEARNING ENGLISH LITERATURE (2006) BY ELLIE CHAMBERS \& MARSHALL GREGORY

Terminology: Analysis
Part of Speech: N
Frequency: 50
Meaning (in context): A careful examination of something
Example: Taking their cue from teachers, over time they may learn
to adopt the detached, precise 'voice' of critical analysis.
Terminology: Author
Part of Speech: N
Frequency: 91
Meaning (in context): A person who creates a literary work
Example: Clearly, the courses most commonly provided in UK
literature departments are (still) period- and style-based, with
Shakespeare as the only single-author course identified (though no
doubt the traditional canon is well represented within many of the
courses).
Terminology: Canon
Part of Speech: N
Frequency: 22
Meaning (in context): A literary work considered important or in
high quality
Example: Planning the curriculum means first identifying the
overarching aims of the programme of study: in practice, this means
that as teachers we answer the 'what should I be teaching, and why?'
questions for ourselves in the light of our knowledge and experience
of literary study, our understanding of the discipline's nature and
purposes, our interpretation of the canon, knowledge of our particular
students, and our practical circumstances.
Terminology: Character
Part of Speech: N
Frequency: 39

\section{Meaning (in context): A person/animal in a literary work}

Example related to literature: The only other characters in the story who even know the young boy are his aunt and uncle, but they're clearly not the narrators, so where does this other point of view come from?

\section{Terminology: Character}

Part of Speech: N

Frequency: 39

Meaning (in context): Qualities of a person that differentiates from others

Example related to teaching literature: They are not so much taught directly as modelled by teachers; they are the features of mind and character that students remember about their teachers often well beyond the years of their higher education - the teachers' enthusiasm for the subject, their fairness, their sensitivity to others, their intellectual playfulness - or not.

\section{Terminology: Interpretation}

Part of Speech: N

Frequency: 49

Meaning (in context): A way in which something is understood

Example related to literature: As we just saw, appropriate interpretation of meaning is shaped and bounded - by the text's genre and form, and by the full range of circumstances of its inception and its reception including the theoretical-critical considerations brought to bear on it.)

Example related to teaching literature: The beginning stages of Latin and Greek do not provide occasions for student interpretation'; students can't have independent opinions about semantics, syntax, tenses, inflections and the like.

\section{Terminology: Pedagogy}

Part of Speech: N

Frequency: 73

Meaning (in context): The study of teaching method

Example related to teaching literature: Traditional pedagogy in literature classes has its roots in the ancient pedagogy of classical language instruction.

Terminology: Reading

Part of Speech: N

Frequency: 164

Meaning (in context): An act of enjoying and praising literary works. Example related to literature: Belles-lettristic writing about literature developed the model of a thoughtful person sitting down with a literary work of life-long acquaintance and writing his or her reactions to that work, often in an impressionistic way but also in a way informed by additional reading that was both wide and deep, intelligence that was flexible and far ranging, thoughtfulness that tended to concentrate on moral issues central to the universal task of making a life, and an analytical sensibility that was not professional in orientation but nevertheless powerfully attentive to literary details, nuances, tones and linguistic suggestiveness of all sorts.

Example related to teaching literature: And so we explore some of the main 'problems' involved in teaching Literature (teaching close

reading, theory and writing) while also demonstrating some of

Literature's main teaching methods (the seminar, tutorial and workshop).:

\section{Terminology: Writing}

Part of Speech: N

Frequency: 221

Meaning (in context): An act of producing literary works.

Example related to teaching literature: And so we explore some of the main 'problems' involved in teaching Literature (teaching close reading, theory and writing) while also demonstrating some of Literature's main teaching methods (the seminar, tutorial and workshop). 
TABLE II

TERMINOLOGIES IN TEACHING LITERATURE ON TEACHING HOLOCAUST LITERATURE AND FILM. (2008) BY ROBERT EAGLESTONE \& BARRY LANGFORD (ED.)

Terminology: Analysis
Part of Speech: N
Frequency: 34
Meaning (in context): A careful examination of something
Example: While teaching typically takes the form of group
discussions, often led by students, prior to the screening of Nuit et
brouillard I deliver a short lecture introducing key concepts and
arguments in the debates outlined above to contextualize analysis of
the two films.

Terminology: Anthology

Part of Speech: N

Frequency: 3

Meaning (in context): A collection of poems or short stories; esp

from various authors

Example: For example, Browning's Ordinary Men is one of the most accessible recent historical texts about the Holocaust and one from which excerpts are regularly made available for literature students (from example, in Langer's Art from the Ashes anthology).

\section{Terminology: Author}

Part of Speech: N

Frequency: 50

Meaning (in context): A person who creates a literary work

Example: On the one hand, testimony texts do stand independently from their authors and reveal all sorts of things the authors could not have known, or known explicitly.

\section{Terminology: Character}

Part of Speech: N

Frequency: 17

Meaning (in context): A person/animal in a literary work.

Example: a "historical ending" (information on the post-war histories of the characters in Schindler's List, the return of Cinque to Africa).

Terminology: Drama

Part of Speech: N

Frequency: 6

Meaning (in context): A kind of literary work acted by actors

Example: Following the Milgram experiments on obedience to authority - wonderful as a metaphor or pieces of contemporary drama, poor as science. Browning hypothesizes that any human actor from any time could - through peer-pressure and propaganda-become a perpetrator.

Terminology: Evaluation

Part of Speech: N

Frequency: 2

Meaning (in context): The act of giving opinion about the quality of something with careful consideration.

Example: What follows is a reflection on some of the issues that arose during the planning, teaching, and evaluation of this course.

Terminology: Pedagogy

Part of Speech: N

Frequency: 25

Meaning (in context): The study of teaching method

Example related to teaching literature: But to see these as oppositions is perhaps a mistake: perhaps they mark phases in a dialectics, awaiting research and reflection on Holocaust pedagogy as the area develops and deepens.

Terminology: Writing

Part of Speech: N

Frequency: 91

Meaning (in context): An act of producing literary works.

Example: Falconer shows not only how Levi's writing is itself clearly and strongly influenced by that tradition (as an Italian writer, Levi of course bears a profound debt of influence to Dante), but also how subsequent infernal narratives operate in the shadow of "our Holocaust inheritance."

Example related to teaching literature: In part this is to do with disciplinary expectations: literature and film students experience writing about the past in the genre of academic history differently from history students, who are more used to historical controversy and the necessarily contingent nature of historical argument, and so less prone to taking it as authoritative.

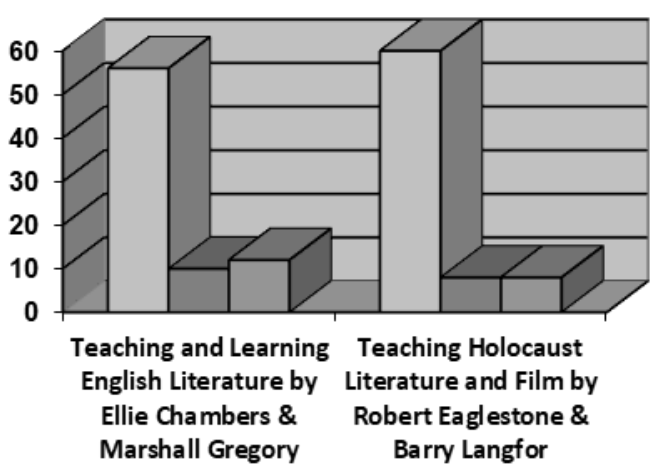

Fig. 1 The total frequency of terminology appearances in Teaching and Learning English Literature by Ellie Chambers \& Marshall Gregory and Teaching Holocaust Literature and Film by Robert Eaglestone \& Barry Langfor (Ed.)

The data found fall into four categories, which are terminologies linked to authors, readers, literary work, and literary theory and criticism. Examples of terminologies related to authors in Teaching and Learning English Literature by Ellie Chambers and Marshall Gregory are 'author' with 91 words, 'writer' with 27 words, and 'rhetoric' with 15 words, while in Teaching Holocaust Literature and Film by Robert Eaglestone and Barry Langfor (ed.), the examples of terminologies related to authors are 'author' with 50 words, 'writer' with 45, and 'rhetoric' with 11 words. These words refer to the authors themselves, excluding 'rhetoric' that does not mean author, but the act used by author to persuade readers or audiences to enjoy the literary works. These words are related to expressive approach proposed by Abrams (1953). The expressive approach believes that literary works are authors' ideas manifestation that is to deliver to readers or audiences.

Meanwhile, in these two books, there are terminologies related to readers or audiences of literary works. Some provided in Teaching and Learning English Literature by Ellie Chambers and Marshall Gregory are 'reading' with 164 words, and 'sensibility' with 5 words. Besides, in Teaching Holocaust Literature and Film by Robert Eaglestone and Barry Langfor (ed.), terminologies related to readers are 'reading' with 102 words, 'sensibility' with 2 words. 'Reading', in this scope, means an act of enjoying and praising literary works, and 'sensibility' means the reader's ability to experience and understand deep feelings in literary works. These words are related to pragmatic approach which considers readers or audiences as the ones whom literary works rely on how to be interpreted (Abrams, 1953). Further, Hans Robert Jauss (1982) states that literary works and readers are dialectical.

Next, terminologies found in the two books are related to the literary work itself. They are 'traditional' with 22 words, and 'ending' with 24 words found in Teaching and Learning 
English Literature by Ellie Chambers and Marshall Gregory. On the other hand, in Teaching Holocaust Literature and Film by Robert Eaglestone and Barry Langfor (ed.), there are 'traditional' with 13 words, and 'ending' with 11 words. 'Traditional' means being a part of certain beliefs, customs, or ways of lives of a group of people that have not changed for a long time, while 'ending' means the last part of literary works. These words are related to objective approach (Abrams, 1953).

Last, the terminologies found are related to literary theory and criticism. They are 'theoretical' with 74 words, and 'critical' with 141 words which are found in Teaching and Learning English Literature by Ellie Chambers and Marshall Gregory. Meanwhile, there are 'theoretical' with 48 words, and 'critical' with 75 words in Teaching Holocaust Literature and Film by Robert Eaglestone and Barry Langfor (ed.). 'Theoretical' means being linked to ideas or principles in which literature is based, while 'critical' means according to the judgement of critics of art, music, literature, and others.

Further, among the terminologies found, there are some terminologies used in a sentence related to the teaching literature activity. In Teaching and Learning English Literature, it is "interpretation" with 49 words and used in a sentence, "the beginning stages of latin and greek do not provide occasions for student 'interpretation'; students can't have independent opinions about semantics, syntax, tenses, inflections and the like".

Additionally, in Teaching Holocaust Literature and Film, it is "reading" with 102 words in a sentence, "reading groups, set up informally with academic support, might also form a useful bond to deal with these issues." Both terminologies are in line with the steps of teaching literature based on Leslie Stratta (in Endraswara, 2005). "Interpretation" is the second step of teaching literature in which the students are asked to explore their opinion or idea towards the literary work they enjoy. Besides, "reading" is a part of the first step, which is tuning. It means that through the process of reading, the students are familiarized to the literary work in order to understand the literary work's content.

Other than that, there is a terminology that has two definitions in Teaching and Learning English Literature. One definition is related to literature, while the other is related to teaching literature. The terminology is "character". In literature, it means "A person/animal in a literary work". The example of sentence is "The only other characters in the story who even know the young boy are his aunt and uncle, but they're clearly not the narrators, so where does this other point of view come from?" While in teaching literature, "character" means "Qualities of a person that differentiates from others". The example is "They are not so much taught directly as modelled by teachers; they are the features of mind and character that students remember about their teachers often well beyond the years of their higher education - the teachers' enthusiasm for the subject, their fairness, their sensitivity to others, their intellectual playfulness - or not." To this, it can be inferred that the use of one terminology or word in a text can have various meanings depending on the context that is called as homonym. It is in line with Retnomurti's argument (2021: 25), "It is distinguished from monosemy, where one form is related to one meaning, and homonymy, where one form is related to two or several unrelated meanings".

\section{CONCLUSIONS}

Both books, Teaching and Learning English Literature by Ellie Chambers and Marshall Gregory, and Teaching Holocaust Literature and Film by Robert Eaglestone and Barry Langfor (ed.) talk about teaching literature. in number, there is no significant difference between them. No literary terminology that is more than 250 words. Besides, since they talk the same scope, the meanings of the terminologies are the same. Further, both present different use of terminologies. In some sentences, the terminologies are used to explain something closer to literature, yet in some other sentences, the terminologies are used to describe or explain the things related to teaching literature.

\section{REFERENCES}

Abrams, M.H. (1953). The mirror and the lamp: Romantic theory and critical tradition. Oxford: Oxford University Press.

Akhmetova, A., \& Yayli, D. (2019). Pre-service EFL teachers' engagement with movie segments in an advanced reading class. The Literacy Trek, 5(1), 5986.

Budiwiyanto, Adi. (2014) Korpus dalam penyusunan kamus. Badan Bahasa. Retrieved from http://badanbahasa.kemdikbud.go.id/lamanbahasa/c ontent/korpus-dalam-penyusunan-kamus

Chambers, Ellie \& Marshall Gregory. (2006). Teaching and learning English literature. California: Sage Publications.

Compagno, Dario. (2012). Theories of authorship and intention in the twentieth century: an overview. Journal of Early Modern Studies, 1(1), 37-53. http://www.fupress.com/bsfm-jems

Eaglestone, Robert \& Barry Langfor (Ed.). (2008). Teaching holocaust literature and film. London: Palgrave Macmillan.

Endraswara, Suwardi. (2005). Metode dan Teori Pengajaran Sastra. Yogyakarta: Buana Pustaka.

Hartmann, Reinhard R. K. (2005). Pure or hybrid? The development of mixed dictionary genres. Linguistics and Literature 3(2), 193 - 208. http://facta.junis.ni.ac.rs/lal/lal2005/lal2005-06.pdf

Hasanah, Hasyim. (2017). Hermeneutik ontologis-dialektis Hans-Georg Gadamer. Jurnal At-Taqaddum. 9(1), $1-32$.

https://journal.walisongo.ac.id/index.php/attaqaddu $\underline{\mathrm{m} / \text { article/view/1785/pdf }}$ 
Inan, D. \& Boldan, M.N. (2018). Implementation of readerresponse theory in teaching short story. The Literacy Trek, 4(2), 63-76.

Iser, Wolfgang. (1974). The implied reader: patterns of communication in prose fiction from bunyan to beckett. Baltimore: The Johns Hopkins University Press.

Jauss, Hans Robert. (1982). Toward an aesthetic of reception. Trans. Timothy Bahti. Minneapolis: University of Minnesota Press.

Karpova,Olga. (2019). Modern English dictionaries: A foreign user's view. Respectus Philologicus, 36(41), 11-18. https://www.journals.vu.lt/ respectusphilologicus/article/view/14623/13590

Klarer, Mario. 1999. An Introduction to Literary Studies. London and New York: Routledge.

Klarer, Mario. (2004). An Introduction to Literary Studies. London: Psychology Press.

Laurenson, D., \& Swingewood, A. (1972). The sociology of literature. London: MacGibbon \& Kee

Lazar, G. (1993). Literature and Language Teaching. Cambridge: Cambridge University Press.

Permanaludin, Udayani. (2017). Strategies of English Literature Teaching at English Literature Undergraduate Program at Sunan Gunung Djati State Islamic University. Jurnal Al-Tsaqafa, 14(1), 183-194.

https://journal.uinsgd.ac.id/index.php/jat/article/do wnload/1799/1198

Retnomurti, A.B. (2021). English Homonym and Polysemy Words Through Semantic Approach: Novels Woy \& The Dancer. Deiksis., 13(1), 21-35. https://journal.lppmunindra.ac.id/index.php/Deiksis /article/view/6608/3705, doi: 10.30998/deiksis.v13i1.6608

Wardani, A.N., \& Adityo. (2021). Investigating Literary Terminologies to Accomplish Literary Research and Enjoyment: A Corpus Study. Journal of Education, Teaching, and Learning (JETL), 6(1), 24-30.

https://journal.stkipsingkawang.ac.id/index.php/JET L/article/view/2317/pdf

Wellek \& Warren. (1963). Theory of literature. London: Penguin Books.

Zemke, John. (2017). Units of measurement: Oral tradition, translation studies and corpus linguistics. SEFAD, (37): 225-238. https://pdfs.semanticscholar.org/35a9/da0054efc2e3 f0bf084ff84198111fcd4d69.pdf? ga=2.191097577. 2141887280.1599383557-480929288.1599383557 